\title{
THE SUBTERRANEAN ASELLIDS OF INDIANA (ISOPODA), WITH THE DESCRIPTION OF CAECIDOTEA DUNLAPORUM, NEW SPECIES
}

\author{
JULIAN J. LEWIS \\ Lewis \& Associates LLC, 17903 State Road 60, Borden, IN, 47106-8608
}

\begin{abstract}
Caecidotea dunlaporum, new species, is described from six localities peripheral to the Indiana karst areas. Endemic to Indiana, this new subterranean species occurs in saturated soil interstices. A second species inhabiting unconsolidated sediments, $C$. beattyi, is reported from Indiana for the first time. This brings to seven the number of obligate subterranean Caecidotea species known from the state. Two species, C. stygia and $C$. rotunda, are primarily found in caves, while $C$. jordani, C. kendeighi, and $C$. teresae are primarily inhabitants of non-cave hypogean habitats. The seven species are divided into the stygia and hobbsi species groups representing two phyletic lines. Conservation statuses of the subterranean isopod fauna include $C$. teresae extirpated from all known sites, $C$. dunlaporum and $C$. jordani critically imperiled, and $C$. rotunda imperiled.
\end{abstract}

\section{INTRODUCTION}

The first report of an isopod from a subterranean habitat in Indiana was Caecidotea microcephala, described by Cope (1872) from material collected in Saltpeter Cave, near Wyandotte Cave, Crawford County. The name of the species was based on Cope's belief that the head was smaller than that of C. stygia described by Packard (1871) from Mammoth Cave, Kentucky. It is not surprising that Cope considered his species as different from C. stygia, considering that in the drawing accompanying his brief description he stitched together the body of an isopod with the egg sacs of a copepod. Fortunately, Packard (1873) synonymized $C$. microcephala with $C$. stygia.

Almost a century elapsed before another isopod species was described from groundwater in Indiana with the discovery of Asellus (=Caecidotea) jordani (Eberly 1966). Fleming (1973) believed this species was synonymous with A. alabamensis, but Lewis and Bowman (1981) examined the type-material and established the validity of $C$. jordani.

Lewis and Bowman (1981) also reported Caecidotea kendeighi (Steeves and Seidenberg 1971) from three collections made by Leslie Hubricht in 1942 from drain tiles in northern Indiana. Hubricht was among the first to recognize the significance of the outlets of field drainage systems, placed to allow cultivation of poorly drained ground, in sampling for groundwater crustaceans occurring in the saturated interstices of soil.

Lewis (1982a) described Caecidotea teresae from drain tile outlets on the campus of Indiana University Southeast in Floyd County. The last species discovered in the state was $C$. rotunda, described from caves in southeastern Indiana and adjacent Ohio (Bowman and Lewis, 1984).

Thus, five species of Caecidotea had been reported from subterranean habitats in Indiana. Herein a new species is described from localities peripheral to the karst, and C. beattyi is reported from Indiana for the first time.

In the following species accounts all collections were made by Julian J. Lewis except where noted otherwise. Type-specimens and many of the other specimens have been deposited in the collection of the United States National Museum (USNM) of Natural History, Smithsonian Institution. Specimens of the new species described herein were assigned USNM catalog numbers. The following abbreviations have been employed: BONWR for Big Oaks National Wildlife Refuge, INAAP for Indiana Army Ammunition Plant, IUS for Indiana University Southeast. Cave locations are recorded in the Indiana Cave Survey database. Other locality data are reported in the English System, since sites were located as measured in the field by car odometer, with data in the specimen vials labelled accordingly; metric data are provided in parenthesis. Directions to a town or other landmark are abbreviated as capital letters, e.g., northwest for NW. The base map (Homoya, 1985) and nomenclature for natural regions of Indiana follows Homoya et al. (1985). Species rarity rankings incorporated are those standardized to conservation agencies in the United States (Master et al., 2000).

\section{Family Asellidae \\ Caecidotea Packard, 1871 \\ Caecidotea dunlaporum, new species \\ Figures 1a, 2-4, 5a}

Material examined-INDIANA: Bartholomew Co.: drain outlet on E side of Highway 31 approximately 1 mile $(1.6 \mathrm{~km}) \mathrm{S}$ intersection with Highway 7, 11 March 2012, 3 males (USNM 1251844); Daviess Co.: drain outlet near intersection of North Fork of Prairie Creek and CR N450E, 7.7 miles (12.4 km) NE Washington, 13 April 2014, 

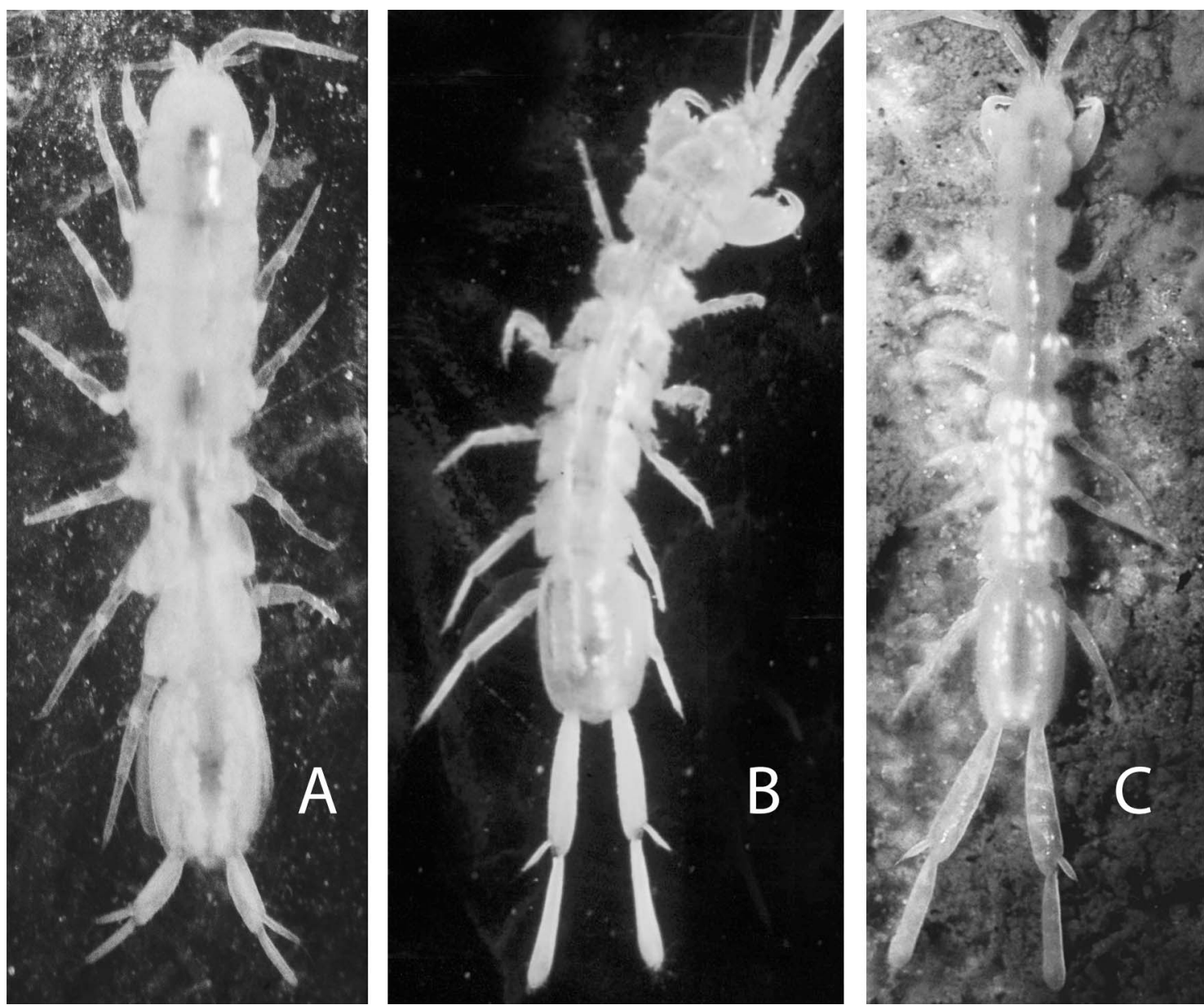

Figure 1. Dorsal view of representative Indiana Caecidotea: (a) C. dunlaporum, n. sp., drain outlet 0.8 mile east of Riley, Vigo County; (b) C. teresae, well, Floyd County; (c) C. jordani, drain outlet, Burns Hollow, Clark County.

1 male fragment (USNM 1251846); drain outlet near intersection of North Fork of Prairie Creek and CR 775E, 8.7 miles (14 km) NE Washington, 13 April 2014, 1 female (USNM 1251847); drain tile outlet near intersection of Thomson Ditch (North Fork of Prairie Creek) and CR 750N, 9.8 miles (15.8 km) NE Washington, 13 April 2014, 3 males, 6 females (USNM 1251848); Clay Co.: drain outlet 2.5 miles $(4 \mathrm{~km}) \mathrm{S}$ of Cory, 8 May 2013, 1 male (USNM 1251845); Vigo Co., drain outlet 0.8 mile $(1.3 \mathrm{~km}) \mathrm{E}$ of Riley on south side of Highway 4 (type-locality: N39 $23^{\prime} 24^{\prime \prime} \mathrm{W} 87^{\circ} 16^{\prime} 57^{\prime \prime}$ ), 16 April 2011, 1 male (USNM 1251842); 22 May 2011, 2 males, 1 ovigerous female (USNM 1251843).

A $6.2 \mathrm{~mm}$ dissected male from Vigo County is the holotype, the other specimens from that locality are paratypes. All material has been deposited in the collection of the United States National Museum of Natural History, Smithsonian Institution.

Description of holotype-Eyeless, unpigmented, 6.2-mm long, body elongate, approximately $5.2 \times$ as long as wide. Margins of head, pereonites, and pleotelson moderately 100 • Journal of Cave and Karst Studies, August 2015

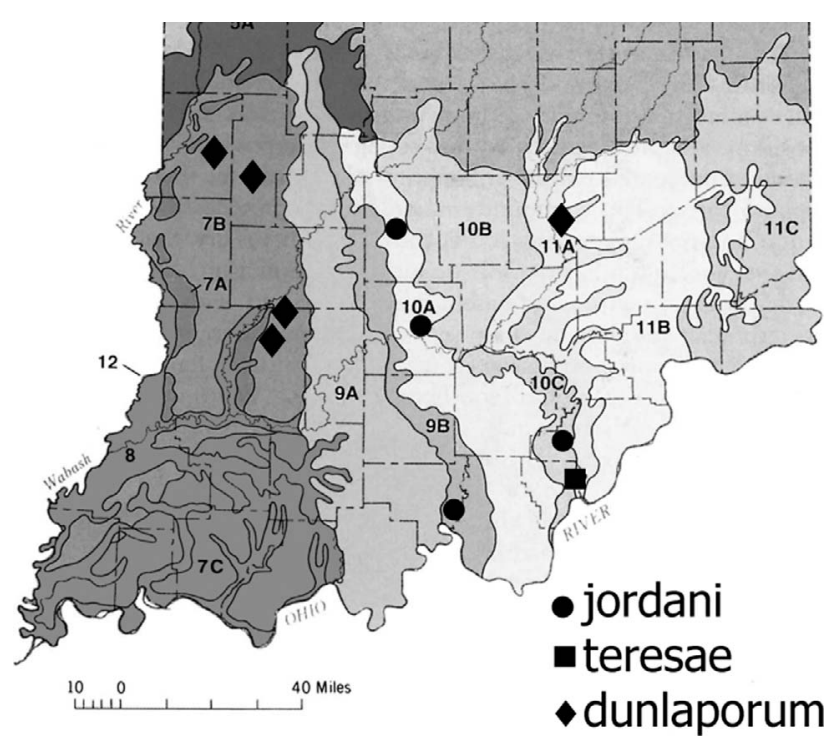

Figure 2. Localities of the three Caecidotea species endemic to Indiana. 


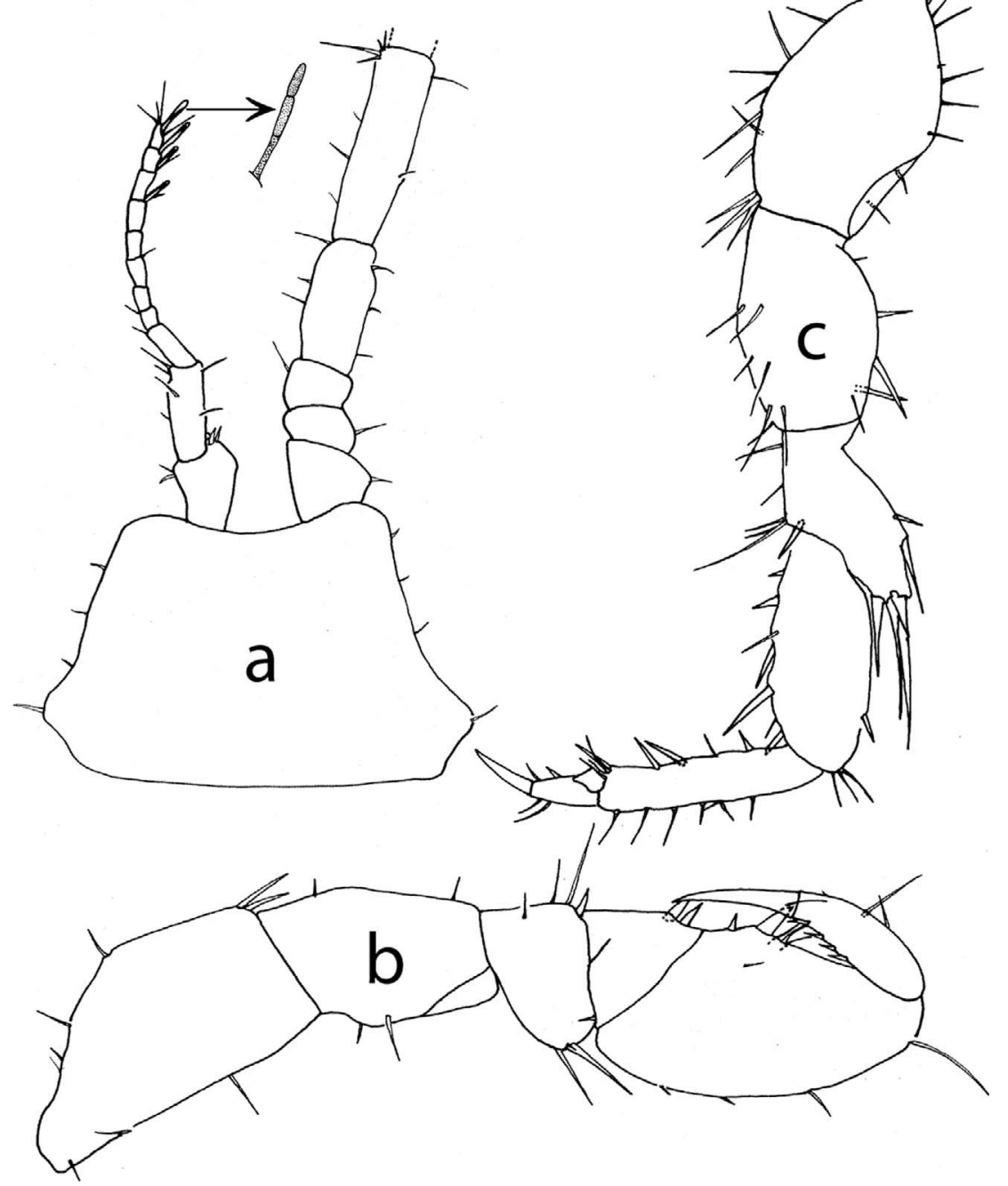

Figure 3. Caecidotea dunlaporum, new species, Vigo County, Indiana, holotype male: (a) head, antenna 1, proximal articles antenna 2; (b) pereopod 1; (c) pereopod 4.

setose. Head with anterior margin concave, approximately $1.6 \times$ as wide as long, post-mandibular lobes moderately produced. Pleotelson approximately $1.5 \times$ as long as wide, caudomedial lobe not produced. Antenna 1 flagellum reaching mid-length of distal article of antenna 2 peduncle, with 8 articles, distal 4 with aesthetascs. Antenna 2 last article of peduncle approximately $1.6 \times$ length of preceding article, flagellum with 34 articles. Mouthparts per the diagnosis of the genus (Lewis 2009).

Pereopod 1 propodus subtriangular, approximately $1.7 \times$ as long as wide, palmar margin with stout proximomedial spine. Dactylus extending beyond palmar margin of propodus approximately $1 / 3$ length of carpus. Pereopod 4 as figure $3 \mathrm{c}$.

Pleopod 1 slightly longer than pleopod 2, protopod approximately $0.7 \times$ length of exopod, 4 retinacula; exopod approximately $2.2 \times$ as long as wide, tapering slightly toward apex, elongate setae on lateral margin.
Pleopod 2, protopod subquadrate, about $1.4 \times$ as long as wide; exopod slightly longer than endopod, proximal article with 2 lateral plumose setae, distal article ovate, with 7 plumose setae along margins increasing in size at apex; endopod with broadly rounded basal apophysis, tip with 2 parallel processes extending distolaterally in anterior view: (1) cannula short, conical, (2) lateral process short, extending slightly beyond margin of endopod, apically blunt.

Pleopod 3 exopod, distance proximal to transverse suture about $0.65 \times$ length of distal part; 6 elongate plumose setae along distal margin. Pleopod 4 exopod with sigmoid false sutures, proximolateral margin with numerous setules. Pleopod 5 exopod without setation. Uropods slightly shorter than pleotelson, rami shorter than peduncle.

Remarks-Among some species of Caecidotea, one or more prominent spines along the palmar margin of the male gnathopod are replaced by processes in larger

Journal of Cave and Karst Studies, August 2015•101 

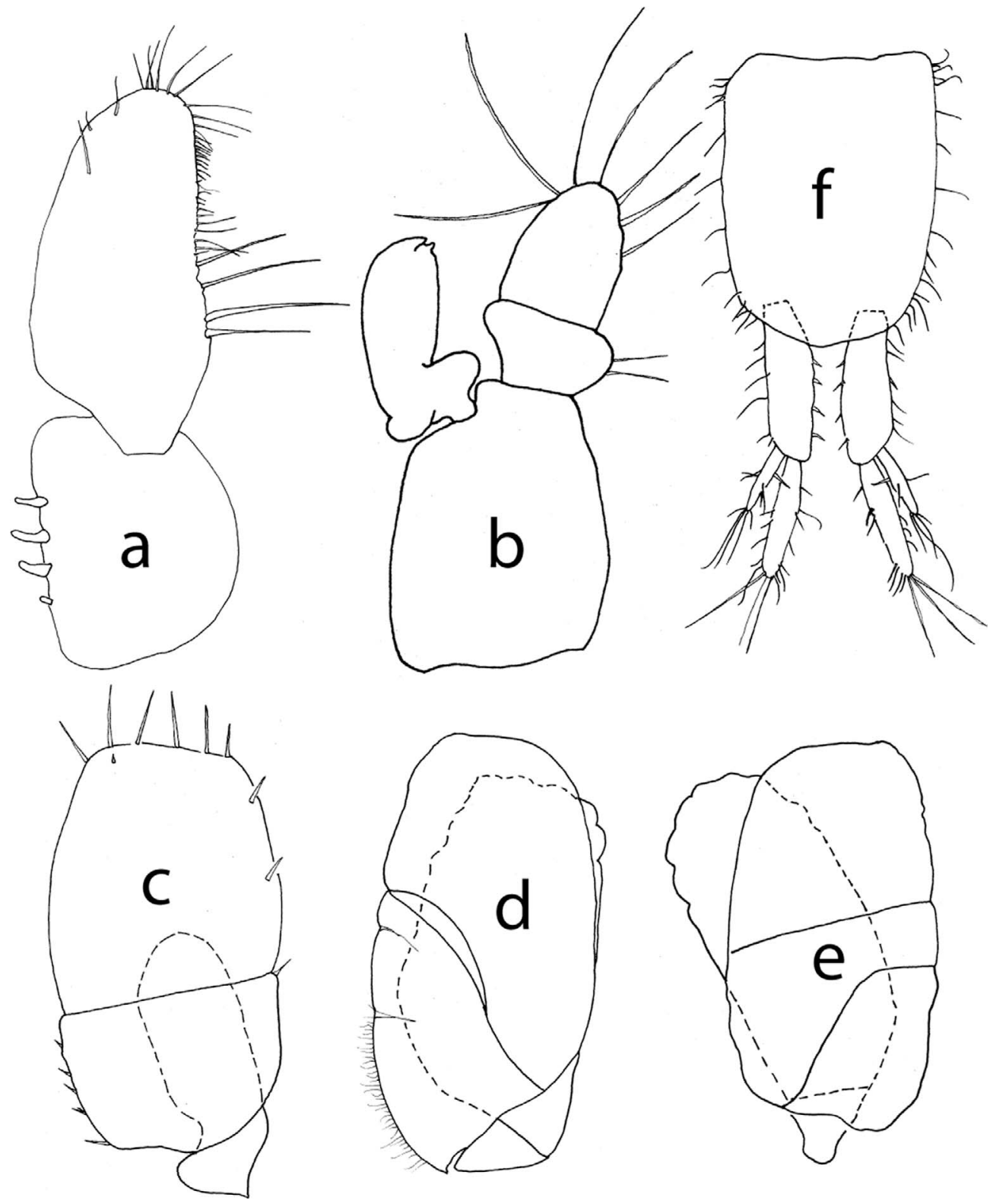

Figure 4. Caecidotea dunlaporum, new species, Vigo County, Indiana, holotype male: (a) pleopod 1, (b) pleopod 2, (c) pleopod 3, (d) pleopod 4, (e) pleopod 5, (f) pleotelson and uropods.

specimens. The palmar margin of $C$. dunlaporum has such a large proximal spine, but in none of the material examined was it replaced by a process, including an 8.5 $\mathrm{mm}$ male from the Bartholomew Co. sample.

Etymology-This species is named in honor of Keith Dunlap and his sister Cynthia Rothrock in recognition of their stewardship of the land and a lifelong dedication to karst conservation. The suggested vernacular name is Dunlap's groundwater isopod.

Habitat and range-This species occurs in unconsolidated sediments of glacial origin. In the sites in Vigo, Daviess, and Clay counties, the field drainage systems from which the specimens were collected were placed in loess that is characteristically six feet or more in thickness, with underlying till (McCarter, 1982; Montgomery, 1974). The drain outlet in Bartholomew County is in soil consisting of loamy glacial outwash (Brownfield, 1976).

A distance of $127 \mathrm{~km}$ is spanned by the collection sites. The sites in Vigo, Daviess, and Clay counties occur in the Southwest Lowlands Natural Region associated with the bottomlands of the Wabash River. The region was covered during the Illinoian glaciation and lies about $25 \mathrm{~km}$ south of the Wisconsinan glacial boundary. The Bartholomew County site is just within this boundary in the Scottsburg Lowlands.

Ecological notes-The type-locality was visited on 8 May 2013 for the purpose of collecting additional material for genetic analysis. At that time the water flowing from the drain tile was 11 degrees $C$. As an indication of the 

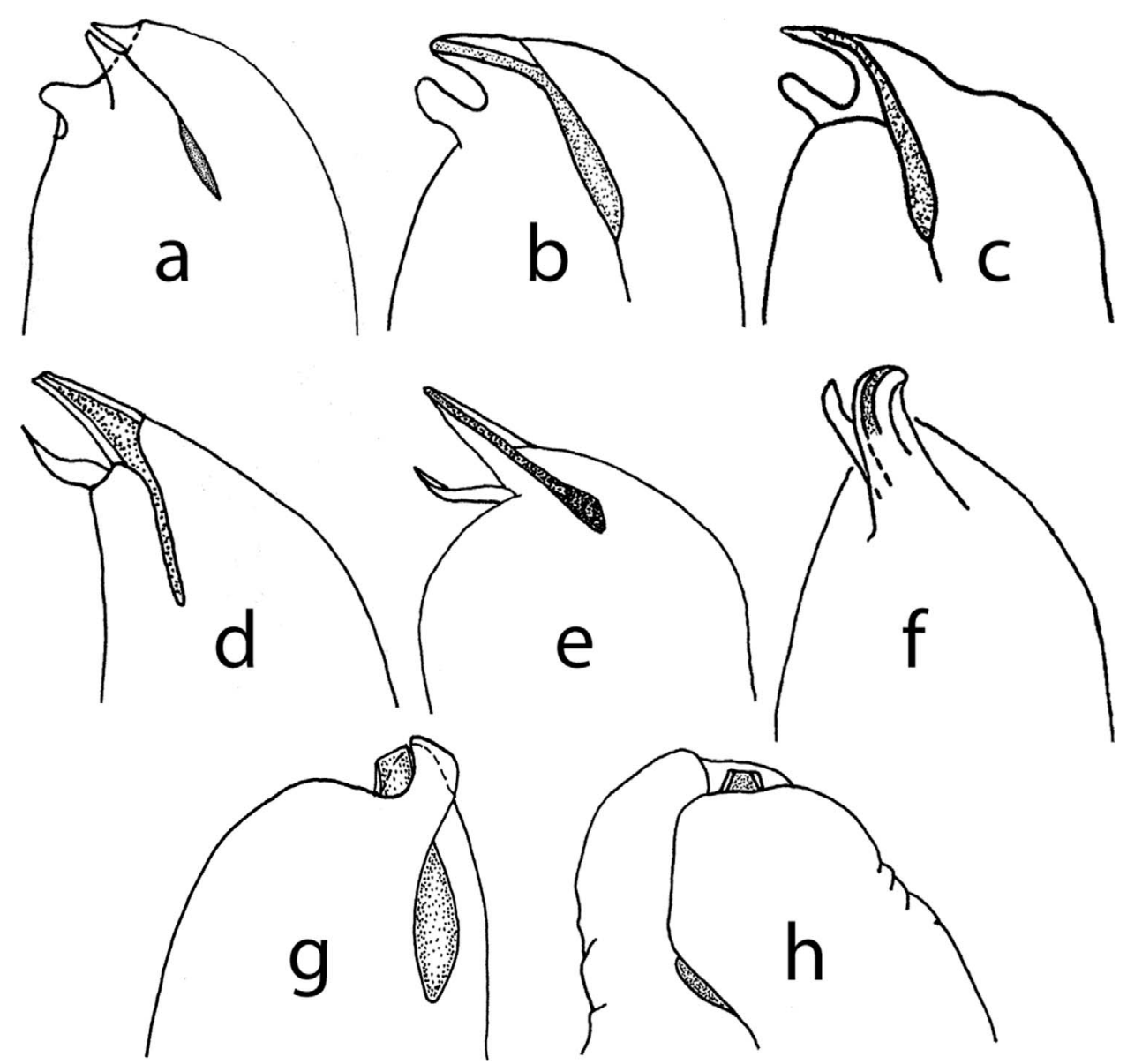

Figure 5. Caecidotea male pleopod 2 endopod tips: (a) C. dunlaporum, Vigo Co., Indiana; (b) C. bicrenata, Hidden River Cave, Hart Co., Kentucky; (c) C. jordani, seep, Burns Hollow, Clark Co., Indiana; (d) C. beattyi, pipe spring, Dixon Springs, Pope Co., Illinois; (e) C. rotunda, Three Raiders Monument Cave, Jefferson Co., Indiana; (f) $C$. stygia, Slider Cave, Jefferson Co., Indiana; (g) C. teresae, drain outlet, Indiana University Southeast, Floyd Co., Indiana; (h) C. kendeighi, drain outlet 1.4 miles W Nottingham, Wells Co., Indiana.

washout rate of the two macroscopic subterranean species occurring in the outlet, 97 amphipods Bactrurus mucronatus were present, but only one C. dunlaporum. A plankton net placed over the drain outlet for 24 hours (8-9 May 2013) collected a similar number of Bactrurus and one Caecidotea, plus numerous specimens of the groundwater ostracod Pseudocandona jeanneli.

The drain outlet in Bartholomew County where $C$. dunlaporum was collected on 11 March 2012 was revisited on 9 May 2013. Remarkably, C. dunlaporum was not found, but several dozen $C$. kendeighi were present on the rocks around the pipe opening. This is the only site in Indiana where two subterranean Caecidotea species have been reported.

Conservation status-Coal strip-mining has caused wholesale destruction of potential habitat and fragmented the range. None of the known localities have any protection, three of which are clustered in the same vicinity. Suggested ranking is S1/G1, critically imperiled.

\section{Caecidotea beattyi Lewis and Bowman}

Figures 5d, 6

Localities-INDIANA: Gibson Co.: drain outlet 2.6 miles $(4.2 \mathrm{~km})$ E Haubstadt; Jasper Co: drain outlet 4 miles $(6.4 \mathrm{~km})$ SSE Rensselaer; Posey Co.: drain outlet 3.9 miles $(6.3 \mathrm{~km})$ SE Wadesville; drain outlet 3.5 miles SE Wadesville; Vanderburgh Co.: drain outlets 2.3 and 3.7 miles $(3.7$ and $5.9 \mathrm{~km}) \mathrm{N}$ Darmstadt.

Habitat and Range - In Indiana, all collection sites for Caecidotea beatty have been at the mouths of field-drain outlets where the isopods were emerging from the saturated soil interstices that they inhabit. Lewis and Bowman (1981) reported the isopods from ditches receiving flow from field drains, wells, seeps, and springs. $C$. beattyi has a predilection for occurring in groundwater near the headwaters of surface streams.

The range of $C$. beattyi encompasses the edge of the Ozark Plateau in eastern Missouri, the northern margin of the Gulf Coastal Plain in southern Illinois, and the till plains of the Central Lowland of Illinois. Previously unknown in Indiana, 


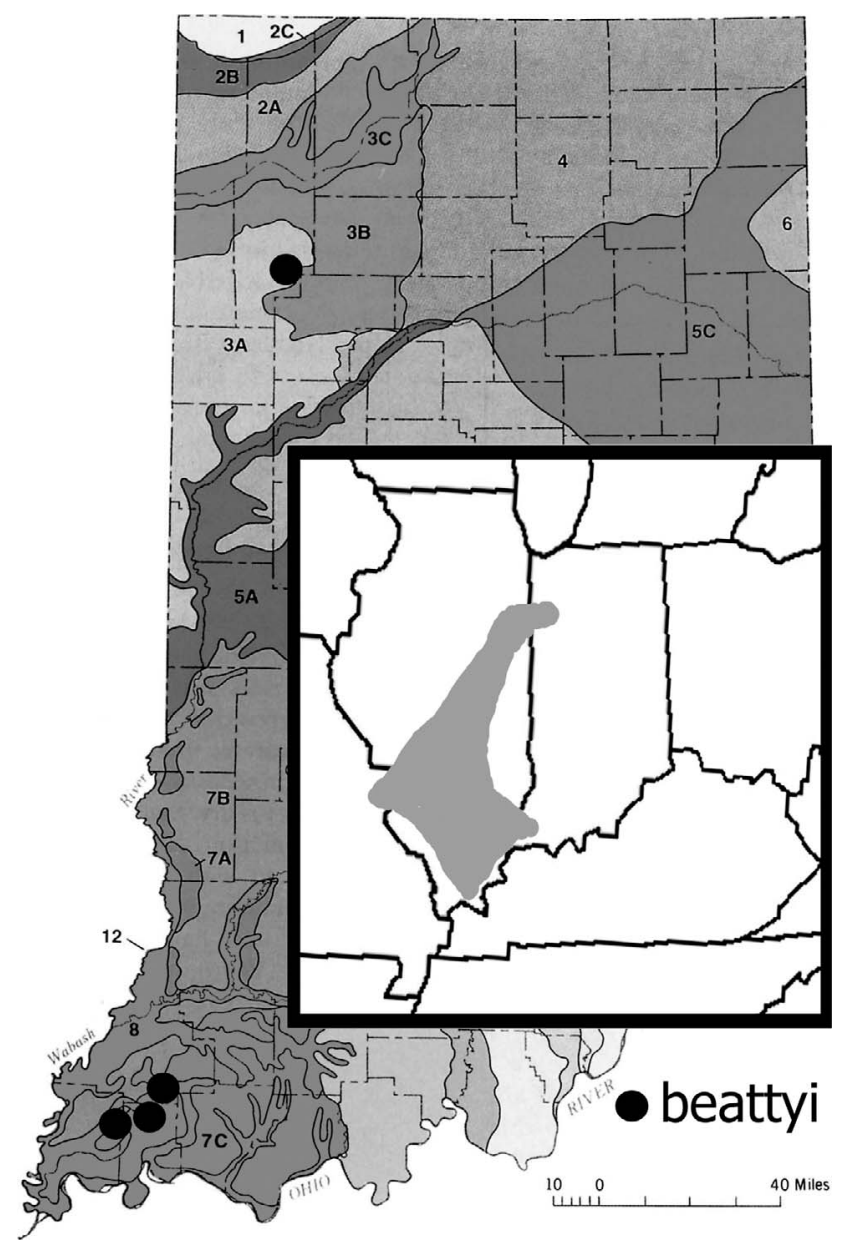

Figure 6. Known range and Indiana localities of Caecidotea beattyi.

it was first discovered in 2011 in northwestern Indiana at a drain outlet in Jasper County in the Grand Prairie Natural Region. Shortly thereafter, $C$. beattyi was discovered at drain outlets in three counties in the southwestern corner of Indiana bounded by the bottomlands of the Ohio and Wabash rivers. Over much of its range $C$. beattyi is sympatric with $C$. kendeighi, but the two species are not known to co-occur.

Vernacular name-Beatty's groundwater isopod.

Conservation status-Caecidotea beattyi is known from a total of 13 localities (six in Indiana) spanning $429 \mathrm{~km}$. The relatively broad range for a subterranean species is deceptive, since this species is sporadic in occurrence, with a penchant for inhabiting groundwater in the headwater zones of streams. Significant portions of the range of $C$. beattyi are heavily impacted by surface coal mining and the use of agricultural pesticides. Suggested status is S2/G2-3, globally imperiled/vulnerable.

\section{Caecidotea jordani (Eberly) Figures 2, 5c}

Localities-INDIANA: Clark Co.: Burns Hollow, 2.6 miles $(4.2 \mathrm{~km})$ ESE Borden; Crawford Co.: Blue River at Rothrock Mill, 3.4 miles $(5.5 \mathrm{~km})$ ENE Leavenworth;
Lawrence Co.: drip pool, Chase Cave, Buddha Karst Preserve; Monroe Co.: seep spring (type-locality) under Jordan Hall, Indiana University Bloomington (Eberly, 1966)

Habitat and Range - Three of the four known localities where Caecidotea jordani has been collected are in Indiana's southcentral karst belt. The type-locality was a seep spring under the Biology Department building at Indiana University. The ground in the sub-basement was treated with termiticides that extirpated the population. In Crawford County, these isopods were found at a parafluvial seep on the bank of the Blue River, as well as a fragment retrieved from a Bou-Rouche sampling well placed a few meters from the seep. The pumpwell was placed one meter deep in a gravel bar that was dry during base-flow conditions on the river. In Chase Cave on one occasion $C$. jordani was found in a drip pool, where the isopods were entering the cave from the epikarst. Outside of the karst, in Clark County, a cluster of three sites in Burns Hollow have produced $C$. jordani from a pipe spring and two seeps.

Vernacular name-Jordan's groundwater isopod.

Conservation status - The range of this species spans $107 \mathrm{~km}$, including the extirpated population in Monroe County. Within this range, the occurrence of Caecidotea jordani is frequently ephemeral, and its seemingly narrow habitat preferences remain poorly understood. Suggested status is $\mathrm{S} 1 / \mathrm{G} 1$, critically imperiled.

\section{Caecidotea kendeighi (Steeves and Seidenberg) Figures 5h, 7}

Localities-INDIANA: Bartholomew Co.: drain outlet 1.7 miles $(2.7 \mathrm{~km}) \mathrm{N}$ intersection Highways 31/46; Benton Co.: drain outlets 2.5 miles $(3.9 \mathrm{~km})$ NNE Ambia, 3 miles $(4.8 \mathrm{~km}) \mathrm{N}$ Boswell, 3 miles $(4.8 \mathrm{~km})$ WSW Fowler, 0.5 mile (0.8) S Fowler; Boone Co.: drain outlet 0.8 mile (1.3 km) SSW Max; Cass Co.: drain outlet 0.3 mile $(0.5 \mathrm{~km}) \mathrm{W}$ Poundstone Corner; Clinton Co.: drain outlet 0.5 mile $(0.8$ km) E Sedalia; Decatur Co.: drain outlets 1.5 miles $(2.4 \mathrm{~km})$ NNW Milford, 2 miles $(3.2 \mathrm{~km}) \mathrm{W}$ Greensburg; Fountain Co.: drain outlet at intersection Highways 28/341, 5 miles $(8 \mathrm{~km})$ E Attica; Grant Co.: drain outlet 5 miles $(8 \mathrm{~km}) \mathrm{W}$ Jonesboro (Koenemann and Holsinger, 2001); Hancock Co.: drain outlet 3 miles $(4.8 \mathrm{~km})$ NE Maxwell; Hendricks Co.: drain outlet 2.5 miles $(3.9 \mathrm{~km})$ NE Lizton; Henry Co.: drain outlets 3.2 miles $(5.1 \mathrm{~km}) \mathrm{W}$ Knightstown (Koenemann and Holsinger, 2001), 3.8 miles $(6.1 \mathrm{~km}) \mathrm{W}$ Knightstown (Lewis and Bowman, 1981); Jasper Co.: drain outlets 5 miles $(8 \mathrm{~km})$ NNE Rensselaer, $2.5(3.9 \mathrm{~km})$ miles SE Rensselaer, 4 miles $(6.4 \mathrm{~km}) \mathrm{N}$ Remington; Jay Co.: drain outlets 1 mile (1.6 km) SW Pennville, 1.3 miles (2 km) NE Pennville at head of Haines Creek; Johnson Co.: drain outlet 3 miles $(4.8 \mathrm{~km})$ NE Whiteland; Lake Co.: drain outlet 3.8 miles $(6.1 \mathrm{~km})$ SE Merrellville (Lewis and Bowman, 1981); Montgomery Co.: drain outlets 1.5 miles $(2.4 \mathrm{~km}) \mathrm{N}$ Manchester, 2 miles $(3.2 \mathrm{~km}) \mathrm{NNW}$ Manchester; Newton Co.: drain outlets 2 and 3 miles (3.2 and 4.8 km) SE Kentland, 4.5 miles (7.2 km) ESE Kentland; Parke Co.: drain outlet 4 miles $(6.4 \mathrm{~km})$ SW Russellville; Porter 


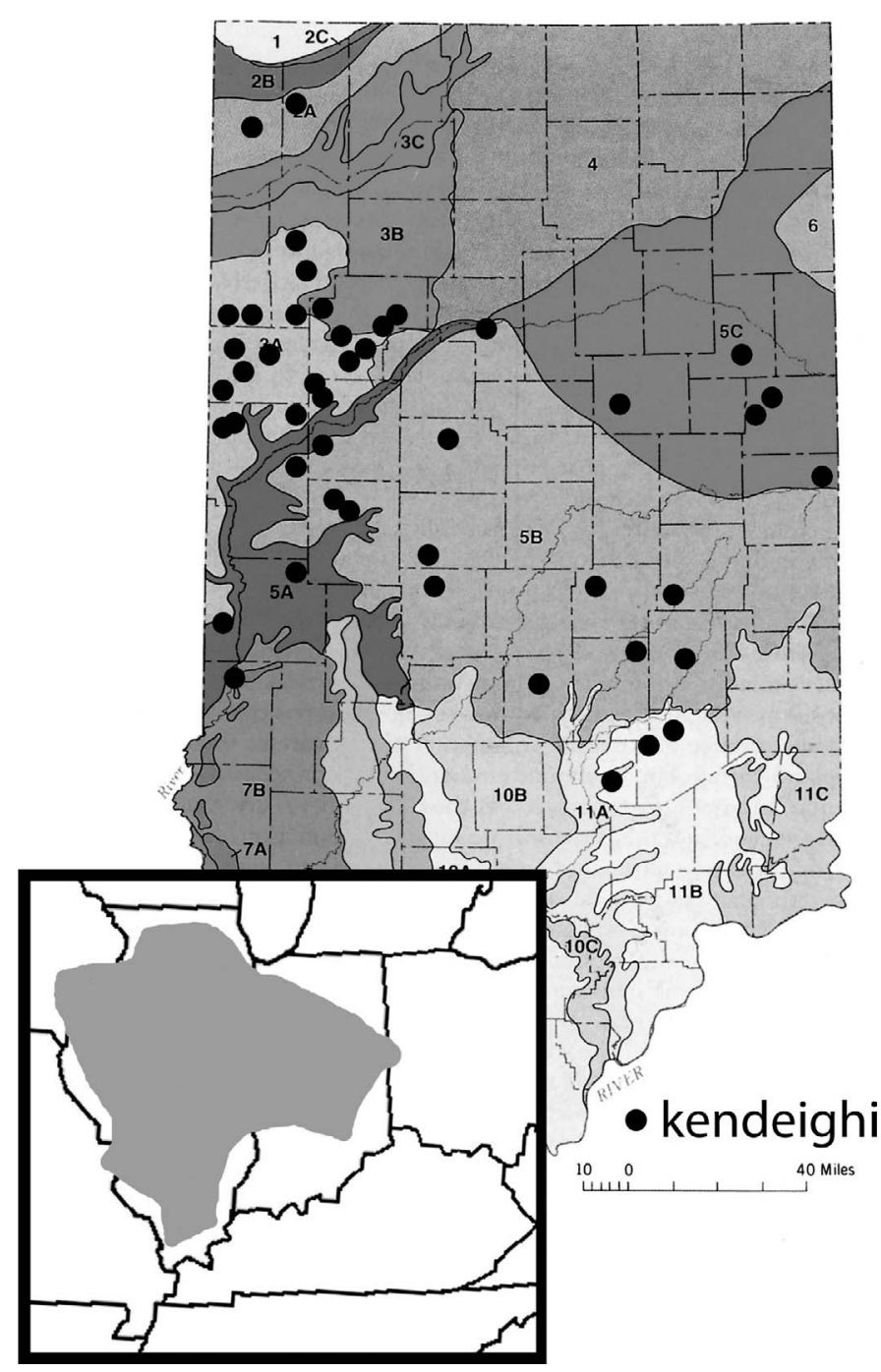

Figure 7. Known range and Indiana localities of Caecidotea kendeighi.

Co.: drain outlet 0.5 mile $(0.8 \mathrm{~km})$ E Deep River (Lewis and Bowman, 1981); Randolph Co.: drain outlet 2 miles (3.2 km) WNW Union City; Rush Co.: drain outlet junction CR 350W/310S, 5.5 miles $(8.9$ km) SSW Rushville; Shelby Co.: drain outlet 2.5 miles $(4 \mathrm{~km})$ ENE Morristown; Tippecanoe Co.: drain outlets 1 mile $(1.6 \mathrm{~km})$ NE Otterbein, 1 mile $(1.6$ $\mathrm{km}) \mathrm{N}$ Montmorenci, 5.8 miles $(9.3 \mathrm{~km}) \mathrm{SSW}$ Montmorenci; Vermillion Co.: drain outlet 2 miles $(3.2 \mathrm{~km})$ E St. Bernice at junction CR 200S/CR 100W; Vigo Co.: drain outlet on Wabash River floodplain 5.7 miles $(9.2 \mathrm{~km}) \mathrm{N}$ Terre Haute; well 9.5 miles $(15.2 \mathrm{~km}) \mathrm{N}$ Terre Haute; Warren Co.: drain outlets 0.2 mile $(0.3 \mathrm{~km}) \mathrm{W}$ intersection Highways 26/41, 2.8 miles $(4.5 \mathrm{~km}) \mathrm{W}$ intersection Highways 26/41, 3.5 miles $(5.6 \mathrm{~km})$ SSW Otterbein; Wells Co.: drain outlet 1.4 miles $(2.3 \mathrm{~km})$ W Nottingham; White Co.: drain outlets 3.3 miles $(5.3 \mathrm{~km}) \mathrm{W}$ Brookston, 3.5 miles $(5.6$ $\mathrm{km})$ WSW Brookston, 6.5 miles $(10.5 \mathrm{~km})$ SSE Wolcott on Bell Ditch, 3.1 miles $(5 \mathrm{~km})$ ENE Wolcott, 4 miles $(6.4 \mathrm{~km})$

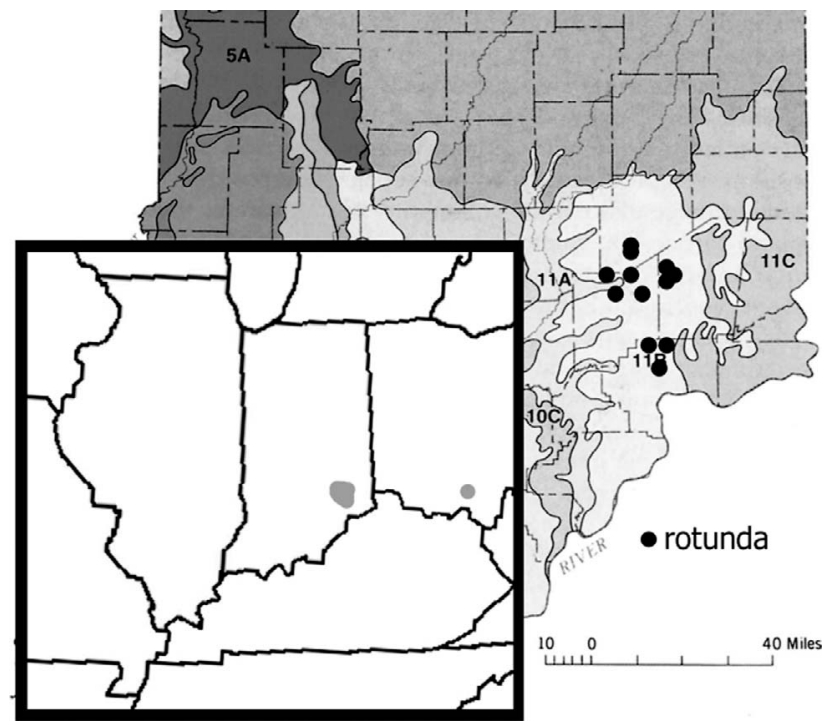

Figure 8. Known range and Indiana localities of Caecidotea rotunda.

SW Reynolds, 4.2 miles $(6.8 \mathrm{~km}) \mathrm{S}$ Reynolds. OHIO: Darke Co.: drain outlets on Madison-Coletown Road, 6.3 miles W $(10.1 \mathrm{~km})$ and $7.0(11.3 \mathrm{~km})$ WSW Greenville.

Habitat and Range-Lewis and Bowman (1981) discussed at some length the habitat of Caecidotea kendeighi. To summarize, the species is an inhabitant of saturated soil interstices, primarily found across glaciated plains from eastern Iowa and Missouri across most of Illinois into Indiana. Lewis and Bowman (1981) reported C. kendeighi from three counties in Indiana, to which are now added records from another 24 counties. The Ohio localities reported above are the first for the state.

Vernacular name-Kendeigh's groundwater isopod.

Conservation status - The range of Caecidotea kendeighi spans almost $500 \mathrm{~km}$. Although apparently secure, concerns for this species include use of agricultural pesticides through much of its range, septic contamination of groundwater, and habitat destruction by surface coal mining and other forms of human encroachment. Sampling suggests that this isopod (as well as $C$. beattyi and $C$. dunlaporum) is absent from many sites where it probably once occurred. In conducting sampling it was not unusual to visit 10 to 20 drain tiles to find one that was inhabited by isopods. In some cases, such as where sewage gray water was emerging from the outlet, the reason for the absence of isopods was obvious, but in other cases the lack of fauna remains a matter of speculation. Suggested status is $\mathrm{S} 4 / \mathrm{G} 4$, apparently secure.

\section{Caecidotea rotunda Bowman and Lewis Figures $5 \mathrm{e}, 8$}

Localities-INDIANA: Decatur Co.: Faulty and Horsethief caves; Jefferson Co.: BONWR: Charles Bear, Mary Spurgin, Grace Bear Sycamore, John and Daisy Smith, Three Raiders Monument, Edward Prenatt, Glen and Florence Shoots, Sadie, and Juanita Jines caves; Jennings 


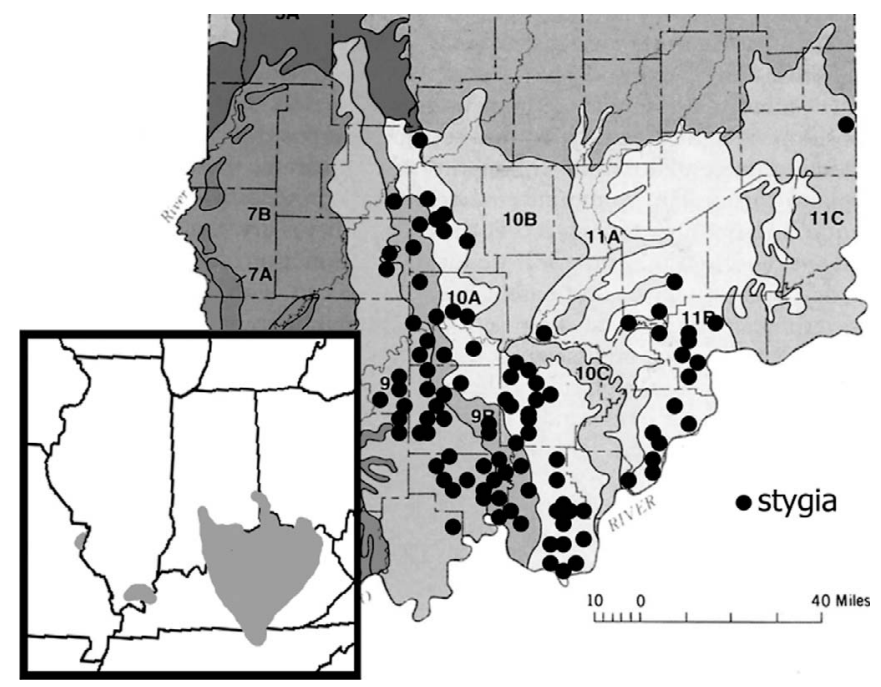

Figure 9. Known range and Indiana localities of Caecidotea stygia.

Co.: Asa and Sarah Edwards (BONWR), Meek, Muscatatuck, and Cave Spring (Wyaloosing Creek) caves, spring below homesite on Middlefork Creek (BONWR); Ripley Co.: BONWR: Thomas and Effie Jessie, Lowell Cooper, Louis Neil, Timber Lodge Spring, and Bernice Chandler caves.

Habitat and range-Bowman and Lewis (1984) reported Caecidotea rotunda from Frost Cave, Pike County, Ohio (type-locality), and four caves in Decatur and Jennings counties in the southeastern Indiana karst. Hobbs and Hazelton (2011) added four localities in Adams and Highland counties, Ohio. Most of the newly discovered Indiana localities are in Big Oaks National Wildlife Refuge in Jefferson and Ripley counties. This species is an obligate inhabitant of cave streams.

Vernacular name - The Ohio population is called the Frost cave isopod in reference to the type-locality. The Indiana populations have been referred to as the Rotund cave isopod.

Conservation status - The range of Caecidotea rotunda spans $200 \mathrm{~km}$, but Ohio localities are separated from the cluster of Indiana sites by the non-cavernous shale beds at the apex of the broad structural uplift known as the Cincinnati Arch. Thus, it is suspected that in actuality two cavernicolous species are present on opposite sides of the Cincinnati Arch. Research is currently being conducted (Lewis, Victor and Lewis, James, in progress) to ascertain if molecular genetic means can distinguish the two suspected species. As currently understood, C. rotunda is known from 19 sites. Suggested status is $\mathrm{S} 2 / \mathrm{G} 2$ in Indiana and $\mathrm{S} 1 / \mathrm{G} 2$ in Ohio, globally imperiled.

\section{Caecidotea stygia Packard}

Figures 5f, 9

Localities-INDIANA: Clark Co.: Ballistics Lab (INAAP), Cave Spring, CC Dryer (INAAP), Godecker Spring, Indian, Jenny Lind Run (INAAP), Moore Brothers Spring, Oak Tree (INAAP), Nine Penny Run Shelter, Peyton
Beechwood, Peyton Spring, RDX (INAAP), Pleasant Run \#2, Poachers (INAAP), Sunset Village, Thomas Crews, and Twin caves, spring at Falls of the Ohio State Park; Crawford Co.: Archibald, Big Circle, Enlows Back Door, Firetail Spring, Hidden Spring, Horseshoe Bend, Hoton Canyon, Little Wildcat, Marengo, Megenity Peccary, Mesmore Spring, Robinson Ladder, Saltpeter, Siberts Well, Wildcat, Wyandotte, and Wymans caves; Dubois Co.: Hall Spring and Vowell caves; Franklin Co.: drain outlet, Springfield Road 1 mile $(1.6 \mathrm{~km}) \mathrm{S}$ Barth; Greene Co.: Ashcraft and Rays caves; Harrison Co.: Baker Hollow, Baseball Bat, Beech Tree Lane, Big Mouth Spring, Big Run, Binkley, Black Medusa, Bradford, Bunck, Bussabargers, Cadaver, Carter Byrnes, Devils Graveyard, Earl Williams, George Miles, Hiser Spring, Horsemans Hideaway, Jingaling Spring, Kings, Klinstiver Spring, Limekiln Hollow, Linds, Manhole, Munsons Spring, Otts Endless Agony, Pipe, Paul Wiseman, Pitmans, Seven Springs, Squire Boone, Stygian River, Tabler Spring, Wallier, and Zollmans caves; Jackson Co.: drain outlet 5.2 miles (8.4 $\mathrm{km}) \mathrm{S}$ Vallonia at intersection SR 135 - CR 700S; Jefferson Co.: Boyd, Cave Spring, Cricket, Deputy Corner, Double, Gray (BONWR), Hardy, Indian, Mud, Slider, Waterfall, and Wilson caves; Jennings Co.: Biehle, Crosley Canyon, Crosley Crack, Garbage Hole, Horsethief, Lowry, Meek, and Skeeter Bluff caves; Lawrence Co.: Brick Pit, Buddha, Bug Ear, Burton Hollow, Connerly, Donnehue, Henshaw Bend, Salts, Shawnee System, Shiloh, and Sullivan caves; Martin Co.: Anderson Road, Bluff House, Gypsy Bill Allen, Redberry, Rose, and Silent Timber caves; Monroe Co.: Frog Pond Fault Pot, Harp Spring, Mayfields, Mays, Patton, and Wayne caves; Orange Co.: Apple, Beaver Attack, Black, Boiling Spring, Bond, Cleveland Spring, Critchfield, Concord Spring, Davids Spring, Diggers Delight, Dillon, Double Cola, Duggins Spring, Freeman Spring, Gallmeiers, Garlow Spring, Grease Gravy Road, Hudelson, Jerrys Jewel, Liars Bluff, Little Africa Pleasure Palace, Lost River System, Mount Horeb, Murray Spring, Nine Springs, Not Our Area, One Bat, Peacher, Piggy Pit, Pine Valley Spring, Roland Wetland, Shale Trail, Silent Brook, Smith Brothers, Snaggy Little, Splorin Hole, Spring Springs, Tucker Dam Quarry, Tucker Lake Spring, Wells, William Cleveland, and Wire Trap Spring caves; Owen Co.: Boone and Porters caves; Perry Co.: Ziegler Cave; Scott Co.: drain outlet 6 miles $(9.6 \mathrm{~km})$ NNE Austin on North Bogardus Road; Washington Co.: Baynes, Benign, Clicks, Charles, Dorsey, Endless, Fredericksburg, Greens Crawl, Karens Pit, May, McNeely Spring, Middle, Mill, Neven Spring, Saltpeter, Suicide, Trinkle, and Waterfall caves.

Habitat and Range-Caecidotea stygia is primarily an inhabitant of caves. Herein it is reported from drain outlets in unconsolidated deposits (i.e., saturated soil interstices) in Jackson and Scott counties in the Scottsburg Lowland that separate Indiana's southcentral and southeastern karst regions. C. stygia was also collected from another drain outlet in Franklin County, adjacent to southwestern Ohio where Bowman and Beckett (1978) reported the isopods from 
seepage areas. This isopod is ubiquitous in caves of the Mitchell Karst Plain and Crawford Upland, composing the southcentral Indiana karst, and the southern half of the southeastern karst, where it is replaced by $C$. rotunda in northern Jefferson County. To the west $C$. stygia occurs in eastern Missouri and across the northwestern Interior Low Plateaus physiographic province in disjunct populations associated with the Shawnee Hills of southern Illinois (Lewis and Bowman 1981). The eastern edge of the range is the karst occurring along the edge of the Cumberland Escarpment in Kentucky and northern Tennessee (Lewis, 1982b).

Vernacular name - Stygian cave isopod.

Conservation status - This is one of the most widespread subterranean isopods in North America, with a range that spans more than $600 \mathrm{~km}$. Suggested ranking is S5/G5, secure.

\section{Caecidotea teresae Lewis}

Figures 2, $5 \mathrm{~g}$

Localities-INDIANA: Floyd Co.: drain outlet below Life Sciences Building at IUS, drain outlet next to small pond by parking lot 5 at IUS, well on Grant Line Road adjacent to IUS campus, and drain outlet near I-265/Grant Line Road interchange.

Habitat and Range - Caecidotea teresae was an inhabitant of saturated soil interstices, and belonged to an assemblage of species that occurred across the Great Plains region in groundwater habitats (Lewis et al. 2006). The range of this species never exceeded a span of two kilometers and has been enveloped by the Louisville metropolitan area. The ground around the buildings above the type-locality on the campus of Indiana University Southeast, New Albany, was treated with termiticides, and the isopods have not been seen since. The area above the other drain outlet on the campus has been turned into an extensive asphalt parking lot. The well was on a farm that has now been bulldozed for on-going development, and the other drain outlet drains oily water from under an automotive repair shop. The species has been extirpated at all known localities. C. teresae was last collected, from the farm well, on 28 April 1995.

Vernacular name-IUS groundwater isopod.

Conservation status - All populations extirpated and all of the land within the narrow range of Caecidotea teresae has been heavily modified by human development. The species is possibly extinct (GX).

\section{ACKNOWLEDGEMENTS}

The description of Caecidotea dunlaporum was supported by funds from the Indiana Academy of Sciences and the Indiana Chapter of The Nature Conservancy. Major funding for the sampling of the fauna came from the Indiana Natural Heritage Program of the Indiana Department of Natural Resources, the U.S. Fish and Wildlife Service, and the Hoosier National Forest, U.S. Department of Agriculture. I thank Michael Homoya for use of his map of the Natural Regions of Indiana with permission from the Indiana Academy of Science.

\section{REFERENCES}

Bowman, T.E., and Beckett, D.C., 1978, A redescription of the troglobitic isopod, Caecidotea stygia, from the environs of Cincinnati, Ohio (Crustacea: Isopoda: Asellidae): Proceedings of the Biological Society of Washington, v. 91, no. 1, p. 294-302.

Bowman, T.E., and Lewis, J.J., 1984, Caecidotea rotunda, a new species of troglobitic asellid from Indiana and Ohio (Crustacea: Isopoda: Asellidae): Proceedings of the Biological Society of Washington, v. 97 , no. 2 , p. $425-431$

Brownfield, S.H., 1976, Soil Survey of Bartholomew County, Indiana: United States Department of Agriculture Soil Conservation Service, 169 p. + maps.

Cope, E.D., 1872, On the Wyandotte Cave and its fauna: American Naturalist, v. 6, no. 7, p. 406-422.

Eberly, W.R., 1966, A new troglobitic isopod (Asellidae) from southern Indiana: Proceedings of the Indiana Academy of Science, v. 75, p. 286-288.

Fleming, L.E., 1973, The evolution of the eastern North American isopods of the genus Asellus (Crustacea: Asellidae), Part II: International Journal of Speleology, v. 5, p. 283-310.

Hobbs, H.H. III., and Hazelton, E.A., 2011, An assessment of the biodiversity of caves and rock shelters of Ohio: Ohio Cave Survey, unpublished report, $120 \mathrm{p}$.

Homoya, M.A., 1985, Map showing the natural regions of Indiana: Indiana Academy of Science, 1 sheet.

Homoya, M.A., Abrell, D.B., Aldrich, J.A., and Post, T.W., 1985, The natural regions of Indiana: Proceedings of the Indiana Academy of Science, v. 94, 245-268.

Koenemann, S., and Holsinger, J.R., 2001, Systematics of the North American subterranean amphipod genus Bactrurus (Crangonyctidae): Beaufortia, v. 51 , no. 1, p. 1-56.

Lewis, J.J., 1982a, A diagnosis of the Hobbsi Group, with descriptions of Caecidotea teresae, n. sp., and C. macropropoda Chase and Blair (Crustacea: Isopoda: Asellidae): Proceedings of the Biological Society of Washington, v. 95 , no. 2 , p. 338-346.

Lewis, J.J., 1982b, Systematics of the troglobitic Caecidotea (Crustaea: Isopoda: Asellidae) of the southern Interior Low Plateaus: Brimleyana, v. 8, p. 65-74.

Lewis, J.J., 2009, Three new species of Caecidotea, with a synopsis of the asellids of Virginia (Crustacea: Isopoda: Asellidae), in Roble, S.M., and Mitchell, J.C., eds., A Lifetime of Contributions to Myriapodology and the Natural History of Virginia: A Festscrift in Honor of Richard L. Hoffman's $80^{\text {th }}$ Birthday: Martinsville, Virginia Museum of Natural History, Special Publication 16, p. 245-259.

Lewis, J.J., and Bowman, T.E., 1981, The subterranean asellids (Caecidotea) of Illinois (Crustacea: Isopoda: Asellidae): Smithsonian Contributions to Zoology 335, 66 p. doi: 10.5479/si.00810282.335.

Lewis, J.J., Graening, G.O., Fenolio, D.B., and Bergey, E.A., 2006, Caecidotea mackini, new species, with a synopsis of the subterranean asellids of Oklahoma: Proceedings of the Biological Society of Washington, v. 119 , no. 4, p. 563-575. doi:10.2988/0006-324X(2006) 119[563: CMNSWA]2.0.CO;2.

Master, L.L., Stein, B.A., Kutner, L.S., and Hammerson, G.A., 2000, Vanishing assets: Conservation status of U.S. species: in Stein, B.A., Kutner, L.S., and Adams, J.S., eds., Precious Heritage, the Status of Biodiversity in the United States: New York, Oxford University Press, p. 93-118.

McCarter, P., Jr., 1982, Soil Survey of Clay County, Indiana: United States Department of Agriculture Soil Conservation Service, 152 p. + maps.

Montgomery, R.H., 1974, Soil Survey of Vigo County, Indiana: United States Department of Agriculture Soil Conservation Service, 121 p. + maps.

Packard, A.S., 1871, On the crustaceans and insects, p. 744-761 in Packard, A.S., and Putnam, F.W., eds., The Mammoth Cave and its inhabitants: American Naturalist, v. 5, no.12, p. 739-761.

Packard, A.S., 1873, On the cave fauna of Indiana: Fifth Annual Report of the Peabody Academy of Science of the Year 1872, p. 93-97.

Steeves, H.R. III., and Seidenberg, A.J., 1971, A new species of troglobitic asellid from Illinois: American Midland Naturalist, v. 85, no. 1, p. 231-234. 